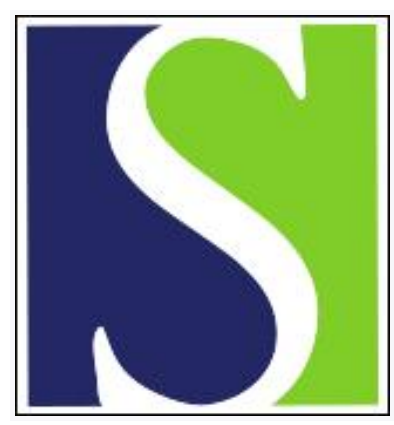

Scand J Work Environ Health 1991;17(2):95-103

https://doi.org/10.5271/sjweh.1721

Issue date: Apr 1991

Paternal occupational lead exposure and spontaneous abortion.

by Lindbohm ML, Sallmen M, Anttila A, Taskinen H, Hemminki K

Affiliation: Institute of Occupational Health, Helsinki, Finland.

The following article refers to this text: 2022;48(7):540-548

This article in PubMed: www.ncbi.nlm.nih.gov/pubmed/2047818

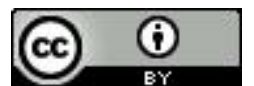




\title{
Paternal occupational lead exposure and spontaneous abortion
}

by Marja-Liisa Lindbohm, MSc, Markku Sallmén, MSc, Ahti Anttila, MSc, Helena Taskinen, MD, Kari Hemminki, MD'1

\begin{abstract}
LINDBOHM M-L, SALLMÉN M, ANTTILA A, TASKINEN H, HEMMINKI K. Paternal occupational lead exposure and spontaneous abortion. Scand J Work Environ Health 1991;17:95-103. A case-referent study was conducted on whether occupational exposure of men to inorganic lead is related to spontaneous abortion in their wives. The men were biologically monitored for lead exposure. The cases (213 spontaneous abortions) and referents ( 300 births) were identified from medical registers. Lead exposure was assessed with blood lead $(\mathrm{PbB})$ measurements and data obtained from a questionnaire. The results did not show a statistically significant relationship between spontaneous abortion and paternal lead exposure among all the study subjects. A significant increase was observed in the risk of those women whose husbands had been monitored $(\mathrm{PbB} \geq 1.5 \mu \mathrm{mol} / \mathrm{l})$ during or close to the time of spermatogenesis. The association between lead exposure and spontaneous abortion was modified also by the age of the wife and paternal alcohol use. The findings suggest that there may be an association between paternal lead exposure and the risk of spontaneous abortion.
\end{abstract}

Key terms: biological monitoring, inorganic lead, reproductive hazards.

Increased numbers of spontaneous abortions, stillbirths, and postnatal deaths were reported for the families of male lead workers already over a hundred years ago (1). There is, however, little information available about whether contemporary levels of paternal lead exposure affect pregnancy outcome. In only one fairly recent study on spontaneous abortion (2) has lead been mentioned as a potential harmful exposure. Beckman et al (2) reported an increased rate of fetal deaths among the wives of smelter workers exposed to several agents, including lead.

A spermatotoxic and gonadotoxic effect of lead has been found for a variety of species, including human beings (3). Lead is also excreted in seminal fluid (4). For lead-exposed workers, an impairment of sperm density, motility, and morphology has been reported $(5-7)$, but negative results have also been obtained $(8,9)$. It has been suggested that poor sperm quality may be one cause of abortion (10).

The aim of this study was to investigate whether occupational exposure of men to inorganic lead is related to spontaneous abortion in their wives. The study population comprised men biologically monitored for lead exposure. Information on pregnancy outcome was obtained from medical registers.

\footnotetext{
1 Institute of Occupational Health, Topeliuksenkatu 41 a A, SF-00250 Helsinki, Finland.
}

Reprint requests to: Ms M-L Lindbohm, Institute of Occupational Health, Topeliuksenkatu 41 a A, SF-00250 Helsinki, Finland.

\section{Subjects and methods}

\section{Identification of the study subjects}

The study population was identified from the following three data sources: the records of men biologically monitored for inorganic lead exposure at the Institute of Occupational Health, the central population register, and the nationwide data base on pregnancies in Finland.

The biological monitoring of lead in blood $(\mathrm{PbB})$ has been a service activity at the Institute of Occupational Health since 1968. In Finland, all workers should be monitored if the $\mathrm{PbB}$ of any worker in the workplace exceeds $2 \mu \mathrm{mol} / 1(1 \mu \mathrm{mol} / \mathrm{l}=20.7 \mu \mathrm{g} / 100 \mathrm{ml})$. The frequency of monitoring depends on the intensity of the lead exposure and varies from one to six times a year (11).

Data on the $\mathrm{PbB}$ measurements were collected from the laboratory records of 1973-1983 and completed with personal identification codes. Altogether 56117 exposure measurements were performed for men in 1973 - 1983, and the identification codes were obtained for $97 \%$ of the measurements. The number of identified men was 19349 .

Information about the wives of the monitored men was obtained from the central population register. The study was restricted to men in their first marriage. The pregnancies of the wives were identified from the nationwide data base on medically diagnosed pregnancies from 1973 to 1983. The data base includes information on all births (International Classification of Diseases (ICD) codes 650-662) and spontaneous abortions (ICD codes 643,645 ) retrieved from the Hospital Discharge Register and hospital policlinic (out- 
patient clinics) records in Finland. The Register covered $94 \%$ of all officially recorded births in Finland in 1973-1983, and we have estimated that about 80$90 \%$ of all recognized spontaneous abortions can be detected from the Register and policlinic records (12).

The study was conducted using a case-referent design. It was restricted to pregnancies which had started during the marriage. All the 18- to 40-year-old wives with a spontaneous abortion were defined as cases. If the woman had had two or more spontaneous abortions, only one was randomly selected. Two referents were selected for every case from the wives who had given birth, but only one pregnancy per woman was included. Only those women who had neither a registered spontaneous abortion nor a registered malformed child during their marriage within the study period qualified as potential referents. The referents were individually matched with the cases for the wife's age at the time of conception within a year, the nearest available match being used. The mean age of the cases and the referents was the same (28.73 years), and the maximum age difference was 0.6 years. Two referents were found for each case, but for six referents no address was obtained.

\section{Estimation of exposure}

Separate questionnaires were mailed to the men and their wives to obtain data on their employment, occupation, workplace, and occupational exposure covering the calendar year of conception of the study pregnancy for the men and the first trimester of the study pregnancy for the women. The men and their wives were asked to describe their work tasks in detail and to indicate potential changes in them and the months of the changes during the time period in question.

The study subjects were asked whether their work included any of the most typical lead-exposing tasks

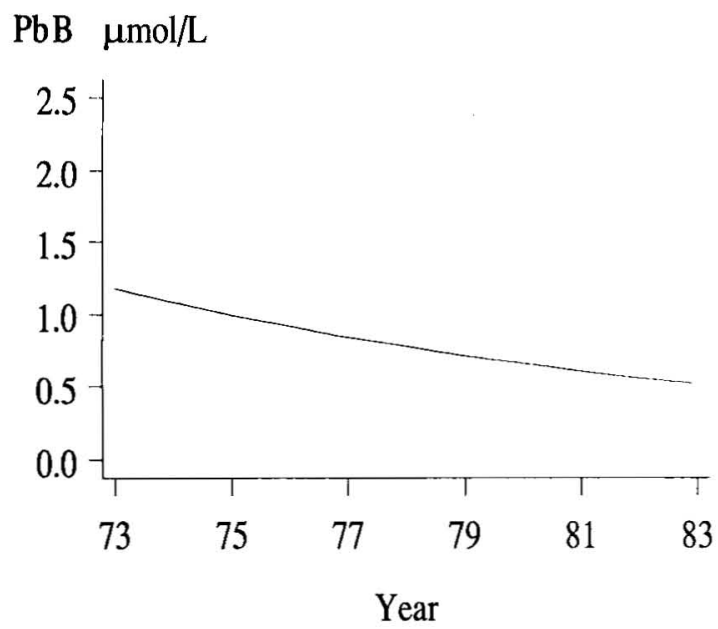

Figure 1. Estimated decreasing trend of lead in blood $(\mathrm{PbB})$ in 1973-1983 among men holding the same job during measurement and spermatogenesis $\{\mathrm{PbB}=\exp [6.315-0.084$ (year)], $\mathrm{R}^{2}=0.172$ ). listed in the questionnaire, for example, soldering or tinning, welding, torch cutting, smelting, spraying, or car repair. They were also asked whether they had handled or if there was lead, cadmium, chromium, nickel, mercury, or other metals in their work environment and in what kind of tasks. Information regarding exposure to solvents or other chemicals, carbon monoxide, and $\mathrm{X}$ rays was requested, too. Furthermore, data on work histories, chronic diseases, smoking, and use of alcohol were also sought. The questions about pregnancy history, lifting at work or at home, acute diseases during the first trimester of pregnancy, and the use of contraception at the beginning of the pregnancy were asked from the wife.

The husband's lead exposure was assessed for the estimated time of spermatogenesis (ie, an 80 -d period before conception). During this time period the formation and maturation of spermatozoa takes place (13). For those holding the same job during the measurement and the spermatogenesis (56\% of the final study population), lead exposure was defined on the basis of $\mathrm{PbB}$ measurements. If the $\mathrm{PbB}$ analysis was carried out during the spermatogenesis, the result was accepted as such. If the husband was monitored both before and after the spermatogenesis period, a timeweighted mean was used.

For those who had been monitored only before or after the study spermatogenesis, another method was adopted. The exponential regression equation $y(t)=\alpha+\beta \cdot t$, where $y(t)=\log (\mathrm{PbB})$ at time $t$ (year of analysis) and $\alpha$ and $\beta$ are constants, was fitted to describe the observed trend in $\mathrm{PbB}$ during 1973-1983. There was a decreasing trend in the $\mathrm{PbB}$ concentrations during the study period among the monitored men (figure 1). A decreasing trend was observed also for the most common fields of activities. To control the effect of time, we estimated the lead exposure from the $\mathrm{PbB}$ measurement nearest the individual's spermatogenesis period of interest by using the fitted $\mathrm{PbB}$ value $\exp \left[\mathrm{y}_{\mathrm{i}}\left(\mathrm{t}_{0}\right)+\hat{\beta}\left(\mathrm{t}_{1}-\mathrm{t}_{0}\right)\right]$ for husband $\mathrm{i}$; where $\mathrm{y}_{\mathrm{i}}\left(\mathrm{t}_{0}\right)=$ logarithm of husband's $\mathrm{PbB}, \mathrm{t}_{0}=$ monitoring date, $t_{1}=$ time of spermatogenesis, and $\hat{\beta}=$ estimated slope of trend $(\hat{\beta}=-0.084, \operatorname{SE}(\hat{\beta})=0.007)$.

The exposure of the men holding a different job during the measurement and the spermatogenesis (44\% of the final study population) was classified by one of the authors into the following five exposure categories: $0.0-0.4,0.5-0.9,1.0-1.4,1.5-1.8$, and $\geq 1.9$ $\mu \mathrm{mol} / \mathrm{l}$. The classification was made without knowledge of who was a case or a referent. The classification was based on the occupation, work description, and lead exposure as reported in the questionnaire and on $\mathrm{PbB}$ measurements in corresponding work.

The two lowest lead exposure categories $(0.0-0.4$ and $0.5-0.9 \mu \mathrm{mol} / \mathrm{l}$ ) were combined to form a lowexposure group, which was used as a reference in the analyses. In an industrialized community environmental exposure can cause a $\mathrm{PbB}$ level of $>0.5 \mu \mathrm{mol} / 1$ among occupationally unexposed persons, but it is not 
probable that it exceeds $1.0 \mu \mathrm{mol} / \mathrm{l}$. The classification of all other exposures was based on the answers to the questionnaire.

\section{Statistical analysis}

The odds ratios for exposure were estimated with the logistic regression model for individually matched data based on the conditional likelihood function. The statistical significance for separate variables was evaluated through a comparison of the standardized regression coefficients with a normal distribution (14).

The potential confounding factors were selected on the basis of prior knowledge on the risk factors of spontaneous abortion. Only those variables which showed an odds ratio (OR) of $>1.5$ in the analysis of the individual variables were included in the final analyses. It was checked that the deletion of the other variables from the model had no essential effect on the odds ratio for lead exposure. Zinc and copper were excluded from the final analyses because the examination of the questionnaires indicated that the reporting of these metals in an open question ("other metals") was obviously unreliable. Potential effect modifiers were tested for inclusion at $\mathbf{P}=0.10$.

In the analysis of the odds ratio for lead exposure by age group, age was classified into two categories ( $<27$ and $\geq 27$ years) on the basis of the median of the maternal age. The lead exposure variable was dichotomous $(\mathrm{PbB}<1.0, \mathrm{PbB} \geq 1.0 \mu \mathrm{mol} / \mathrm{l})$ because the differences in the odds ratios between the old and young families were similar in all the exposure categories with a $\mathrm{PbB}$ value of $\geq 1.0 \mu \mathrm{mol} / 1$, and there were only a few men in the two highest exposure groups. We determined the significance for the homogeneity of the odds ratios for lead exposure in the two age groups by including an interaction variable involving the husband's lead exposure and the wife's age in the logistic model.

A variable controlling missing information was included in the models. The value of this variable was set at one if any of the variables of an observation had a missing value. The missing value of the variable in question was replaced by zero (ie, not exposed).

\section{Response rate and the final study population}

After four mailings the response rate was $73.7 \%$. The referents were slightly more active than the cases (table 1 ). The study pregnancy was reported for $84.1 \%$ of the case families and for $99.7 \%$ of the reference families. Abortions in the years 1978-1983 were confirmed to a higher degree $(92 \%)$ than the abortions from the earlier years $(1973-1977)(76 \%)$. The married couples who did not confirm their pregnancy were excluded from the final analysis.

There were 67 cases $(21.4 \%$ of those who reported the study pregnancy) and $141(18.5 \%)$ referents who had been monitored while in the job held during the spermatogenesis period in question, but the nearest measurement was not within three years of the spermatogenesis. To improve the validity of the lead exposure assessment, these subjects were excluded from the final analysis.

In addition one case and seven referents were omitted because their lead exposure could not be assessed due to incomplete reporting. Four referents who reported a malformed child as the study pregnancy were also excluded.

Further loss of material was due to the individual matching. All the referents with a missing case and the cases with both referents missing were removed. The final study population consisted of 213 cases and their 300 matched referents.

\section{Results}

There were no great differences in the lead exposure between the cases and the referents. The estimated blood lead level of $26.3 \%$ of the cases and $24.0 \%$ of the referents exceeded the Finnish reference value of occupationally unexposed persons $(\mathrm{PbB}<1.0$ $\mu \mathrm{mol} / \mathrm{l})$. Eleven cases $(5.2 \%)$ and 11 referents $(3.7 \%)$ had levels higher than or equal to the health-based limit (1.9 $\mu \mathrm{mol} / \mathrm{l})$ recommended for men by the World Health Organization (WHO). The distribution of the final study population in different exposure categories and by source of information used to estimate the lead exposure is shown in table 2 .

The study subjects worked in numerous fields of industry (table 3 ). There were only slight differences in the distribution of occupations between the cases and the referents. Different kinds of metalware work were the most common occupations. The men in foundry and smelting work had the greatest exposure, $50 \%$ of them being occupationally exposed to lead (PbB $\geq 1.0 \mu \mathrm{mol} / \mathrm{l}$ ) and $35 \%$ having a $\mathrm{PbB}$ value higher than or equal to WHO's recommended health-based limit $(1.9 \mathrm{mmol} / \mathrm{l})$. In addition men doing sheet metal work or electrical work (storage battery manufacture) had $\mathrm{PbB}$ values of $\geq 1.9 \mu \mathrm{mol} / 1$.

Table 1. Response status of the cases and the referents and the final study population.

\begin{tabular}{|c|c|c|}
\hline & Cases & Referents \\
\hline Total population & 515 & 1024 \\
\hline Respondents ${ }^{a}$ & $372(72.2)$ & $763(74.5)$ \\
\hline $\begin{array}{l}\text { Reported the study } \\
\text { pregnancyb }\end{array}$ & $313(84.1)$ & $761(99.7)$ \\
\hline $\begin{array}{l}\text { Sufficient data for lead } \\
\text { exposure assessment }\end{array}$ & 245 & 609 \\
\hline $\begin{array}{l}\text { Final population for } \\
\text { matched analysis }\end{array}$ & 213 & 300 \\
\hline
\end{tabular}

a Percentage of the total in parentheses.

b Percentage of the respondents in parentheses.

c Blood lead measurement in the same job within 36 months from the spermatogenesis, or lead exposure classified on the basis of the questionnaire. 
Table 2. Estimated blood lead $(\mathrm{Pb} / \mathrm{B})$ level of the men during the $80-\mathrm{d}$ period before conception according to information used for classifying the exposure.

\begin{tabular}{|c|c|c|c|c|c|c|}
\hline \multirow[b]{2}{*}{$\mathrm{PbB}(\mu \mathrm{mol} / 1)$} & \multicolumn{2}{|c|}{ Biological monitoring data } & \multicolumn{2}{|c|}{ Questionnaire data } & \multicolumn{2}{|c|}{ Total } \\
\hline & $\begin{array}{c}\text { Cases } \\
(\mathrm{N}=124) \\
(\%)\end{array}$ & $\begin{array}{c}\text { Referents } \\
(\mathrm{N}=161) \\
(\%)\end{array}$ & $\begin{array}{c}\text { Cases } \\
(\mathbf{N}=89) \\
(\%)\end{array}$ & $\begin{array}{c}\text { Referents } \\
(\mathrm{N}=139) \\
(\%)\end{array}$ & $\begin{array}{c}\text { Cases } \\
(\mathrm{N}=213) \\
(\%)\end{array}$ & $\begin{array}{c}\text { Referents } \\
(\mathrm{N}=300) \\
(\%)\end{array}$ \\
\hline $\begin{array}{l}0.0-0.9^{a} \\
1.0-1.4 \\
1.5-1.8 \\
\geq 1.9^{b}\end{array}$ & $\begin{array}{r}61.3 \\
22.6 \\
7.3 \\
8.9\end{array}$ & $\begin{array}{r}65.2 \\
23.0 \\
5.0 \\
6.8\end{array}$ & $\begin{array}{r}91.0 \\
9.0 \\
-\end{array}$ & $\begin{array}{r}88.5 \\
10.1 \\
1.4 \\
-\end{array}$ & $\begin{array}{r}73.7 \\
16.9 \\
4.2 \\
5.2\end{array}$ & $\begin{array}{r}76.0 \\
17.0 \\
3.3 \\
3.7\end{array}$ \\
\hline $\begin{array}{l}\text { Percentage of all } \\
\text { cases/referents }\end{array}$ & 58.2 & 53.7 & 41.8 & 46.3 & 100.0 & 100.0 \\
\hline
\end{tabular}

a The Finnish reference value of the unexposed is $<1.0 \mu \mathrm{mol} / \mathrm{l}$.

$b$ The recommended health-based limit of the World Health Organization is $1.9 \mu$ mol/l for men.

Table 3. Distribution of cases and referents by occupation and the percentage of the subjects with a blood lead $(\mathrm{PbB})$ level of $1.0-1.8$ and $\geq 1.9 \mu \mathrm{mol} / \mathrm{l}$.

\begin{tabular}{|c|c|c|c|c|c|c|c|}
\hline \multirow[b]{2}{*}{ Occupation } & \multirow{2}{*}{\multicolumn{2}{|c|}{$\begin{array}{l}\text { Cases } \\
(\%)\end{array}$}} & \multirow[b]{2}{*}{$\begin{array}{l}\text { Referents } \\
(\%)\end{array}$} & \multicolumn{4}{|c|}{$\mathrm{PbB}$ level } \\
\hline & & & & $\underset{(\%)}{1.0-1.8}$ & & $\begin{array}{c}\geq 1.9 \\
\mu \text { moll } \\
(\%)\end{array}$ & \\
\hline Motor vehicle inspection & 6 & & 2 & - & & - & \\
\hline Smelting and foundry work & 4 & & 6 & 15 & & 35 & \\
\hline Repair of automobiles & 9 & & 10 & 46 & & - & \\
\hline Sheet metal work & 9 & & 7 & 34 & & 10 & \\
\hline Welding & 8 & & 8 & 15 & & 2 & \\
\hline Other iron and metalware work & 8 & & 14 & 23 & & 3 & \\
\hline $\begin{array}{l}\text { Electrical work (including storage } \\
\text { battery work) }\end{array}$ & 6 & & 6 & 21 & & 10 & \\
\hline Painting & 13 & & 9 & 30 & & 2 & \\
\hline Graphic work & 6 & & 5 & 39 & & 4 & \\
\hline Other manufacturing work & 12 & & 16 & 10 & & 1 & \\
\hline Other work & 13 & & 13 & 10 & & - & \\
\hline Unknown or not employed & 6 & & 4 & - & & - & \\
\hline Total percentage ${ }^{a}$ & 100 & (213) & $100 \quad(300)$ & . & & $\cdot$ & \\
\hline \multicolumn{8}{|l|}{ Lead-exposed subjects } \\
\hline Total percentage ${ }^{a}$ & $\cdot$ & & · & 21 & (106) & 4 & (22) \\
\hline
\end{tabular}

a Total number in parentheses.

In the analysis involving the estimated $\mathrm{PbB}$ level only, the odds ratio of spontaneous abortion for lead exposure was 1.4 in the two highest exposure categories ( $\mathrm{PbB} 1.5-1.8$ and $\geq 1.9 \mu \mathrm{mol} / \mathrm{l}$ ), and it did not deviate significantly from unity (table 4 ) when the lowexposure $(\mathrm{PbB}<1.0 \mu \mathrm{mol} / \mathrm{l})$ was used as a reference group. Neither was the trend in the odds ratio statistically significant with increasing level of exposure $(P=0.41)$. The odds ratio for other paternal occupational exposures, smoking, or the use of alcohol was not increased except for copper [OR 2.8, $95 \%$ confidence interval $(95 \% \mathrm{CI}) 1.1-7.0]$. Of the maternal variables, the use of contraception at conception and previous spontaneous abortions were related to the occurrence of spontaneous abortion (OR 2.1, $95 \%$ CI 1.1-3.9, and OR 1.9, $95 \% \mathrm{CI} 1.2-3.2$, respectively).
The "final" model included the following potentially confounding factors: paternal exposure to cadmium and mercury, maternal exposure to organic solvents and mercury, the use of alcohol, parity, contraception, previous spontaneous abortion, and the index of missing information. The adjusted odds ratios of spontaneous abortion for paternal lead exposure were 1.0, 1.3, and 1.6 for the PbB levels $1.0-1.4,1.5-1.8$, and $\geq 1.9 \mu \mathrm{mol} / 1$, respectively (table 5). None of these odds ratios were significantly increased.

We checked the potential confounding effect of previous adverse pregnancy outcome by including only those women who had only one spontaneous abortion and no malformed children during the study period in the analysis. The exclusion of the cases with two or more registered abortions $(\mathrm{N}=30)$ and their refer- 
Table 4. Maternal and paternal exposures among the cases and the referents and the odds ratio of spontaneous abortion, logistic regression models including a single risk factor ( $P$ bB $=$ blood lead)

\begin{tabular}{ccccc}
\hline & \multicolumn{2}{c}{ Exposed } & & \\
\cline { 2 - 5 } Exposure & $\begin{array}{c}\text { Cases } \\
\text { (N) }\end{array}$ & $\begin{array}{c}\text { Refer- } \\
\text { ents } \\
\text { (N) }\end{array}$ & $\begin{array}{l}\text { Odds } \\
\text { ratio }\end{array}$ & $\begin{array}{c}95 \% \\
\text { confidence } \\
\text { interval }\end{array}$ \\
\hline
\end{tabular}

Paternal

Estimated PbB level

\begin{tabular}{|c|c|c|c|c|}
\hline $\begin{array}{r}<1.0 \mu \mathrm{mol} / \mathrm{l} \\
1.0-1.4 \mu \mathrm{mol} / \mathrm{l} \\
1.5-1.8 \mu \mathrm{mol} / \mathrm{l} \\
\geq 1.9 \mu \mathrm{mol} / /\end{array}$ & $\begin{array}{r}157 \\
36 \\
9 \\
11\end{array}$ & $\begin{array}{r}228 \\
51 \\
10 \\
11\end{array}$ & $\begin{array}{l}1.0 \\
1.0 \\
1.4 \\
1.4\end{array}$ & $\begin{array}{l}0.6-1.7 \\
0.5-3.5 \\
0.6-3.4\end{array}$ \\
\hline $\begin{array}{l}\text { Cadmium } \\
\text { Chromium } \\
\text { Nickel } \\
\text { Mercury } \\
\text { Zinc } \\
\text { Copper }\end{array}$ & $\begin{array}{r}13 \\
24 \\
23 \\
4 \\
4 \\
12 \\
14\end{array}$ & $\begin{array}{r}12 \\
34 \\
29 \\
4 \\
7 \\
8\end{array}$ & $\begin{array}{l}1.6 \\
0.9 \\
1.1 \\
1.6 \\
2.2 \\
2.8\end{array}$ & $\begin{array}{l}0.7-3.7 \\
0.5-1.6 \\
0.6-1.9 \\
0.3-8.1 \\
0.8-5.5 \\
1.1-7.0\end{array}$ \\
\hline $\begin{array}{l}\text { Carbon monoxide } \\
\text { Organic solvents } \\
X \text { rays }\end{array}$ & $\begin{array}{r}75 \\
107 \\
10\end{array}$ & $\begin{array}{r}98 \\
145 \\
\text { to }\end{array}$ & $\begin{array}{l}1.1 \\
1.1 \\
1.5\end{array}$ & $\begin{array}{l}0.8-1.7 \\
0.7-1.5 \\
0.6-3.6\end{array}$ \\
\hline $\begin{array}{l}\text { Use of alcohol } \\
\geq 10 \text { drinks a week } \\
\text { Smoking }\end{array}$ & $\begin{array}{r}48 \\
110\end{array}$ & $\begin{array}{r}74 \\
137\end{array}$ & $\begin{array}{l}0.9 \\
1.3\end{array}$ & $\begin{array}{l}0.6-1.4 \\
0.9-1.9\end{array}$ \\
\hline \multicolumn{5}{|l|}{ Maternal } \\
\hline $\begin{array}{l}\text { Lead } \\
\text { Mercury } \\
\text { Carbon monoxide } \\
\text { Organic solvents } \\
\text { X rays } \\
\text { Heavy lifting at workb }\end{array}$ & $\begin{array}{r}6 \\
5 \\
4 \\
14 \\
4\end{array}$ & $\begin{array}{r}11 \\
3 \\
6 \\
12 \\
5\end{array}$ & $\begin{array}{l}0.8 \\
2.7 \\
1.1 \\
1.8 \\
1.4\end{array}$ & $\begin{array}{l}0.3-2.3 \\
0.6-11.4 \\
0.3-3.9 \\
0.8-4.1 \\
0.4-5.2\end{array}$ \\
\hline $\begin{array}{l}5-29 \text { points } \\
\geq 30 \text { points }\end{array}$ & $\begin{array}{l}29 \\
29\end{array}$ & $\begin{array}{l}48 \\
35\end{array}$ & $\begin{array}{l}0.8 \\
1.2\end{array}$ & $\begin{array}{l}0.5-1.3 \\
0.7-2.1\end{array}$ \\
\hline $\begin{array}{l}\text { Use of alcohol } \\
\geq 1 \text { time a week } \\
\text { Smoking } \\
\text { Use of contraception }\end{array}$ & $\begin{array}{r}8 \\
45\end{array}$ & $\begin{array}{r}5 \\
48\end{array}$ & $\begin{array}{l}2.4 \\
1.5\end{array}$ & $\begin{array}{l}0.8-7.3 \\
0.9-2.4\end{array}$ \\
\hline $\begin{array}{l}\text { at conception" } \\
\text { Febrile diseases } \\
\text { Previous spontaneous }\end{array}$ & $\begin{array}{l}26 \\
30\end{array}$ & $\begin{array}{l}18 \\
46\end{array}$ & $\begin{array}{l}2.1 \\
1.0\end{array}$ & $\begin{array}{l}1.1-3.9 \\
0.6-1.6\end{array}$ \\
\hline $\begin{array}{l}\text { abortion } \\
\text { Parity } \geq 3 \text { children }\end{array}$ & $\begin{array}{l}43 \\
17 \\
\end{array}$ & $\begin{array}{l}33 \\
17 \\
\end{array}$ & $\begin{array}{l}1.9 \\
1.6 \\
\end{array}$ & $\begin{array}{l}1.2-3.2 \\
0.7-3.5 \\
\end{array}$ \\
\hline otal & 213 & 300 & . & $\cdot$ \\
\hline
\end{tabular}

a Drink $=1$ bottle of beer, 1 glass of wine $(12 \mathrm{cl})$, or 1 glass of spirits

b The daily lifts were scored as follows: loads weighing $5-9 \mathrm{~kg}=t$ point, $10-19 \mathrm{~kg}=3$ points, and $\geq 20 \mathrm{~kg}=5$ points per lift. The sum of the points describes heavy lifting.

c Includes oral contraceptives, intrauterine devices, and spermicides.

d Includes all self-reported previous spontaneous abortions of the cases and the referents (ie, those before the study period, those during the study period but before present marriage, and those during the study period and within the present marriage).

ents $(\mathrm{N}=43)$, as well as two cases with a registered malformed child and their referents $(\mathrm{N}=3)$, did not essentially affect the results. The adjusted odds ratios of abortion were $1.1(95 \% \mathrm{CI} 0.6-1.9), 1.0(95 \%$ CI 0.4-3.0), and $1.6(95 \%$ CI 0.6-4.2) for the PbB levels $1.0-1.4,1.5-1.8$, and $\geq 1.9 \mu \mathrm{mol} / 1$, respectively.

The odds ratios for lead exposure obtained from a logistic model were similar to those in the final model when the subjects who did not confirm the study pregnancy or who were not monitored within three years of the time of spermatogenesis were included in the model. In addition, the inclusion of time (as a dichotomous variable, 1973-1977 and 1978-1983) in the final model did not essentially affect the results.

In the analyses, corrected estimates of $\mathrm{PbB}$ measurements were used for assessing the exposure of the
Table 5. Adjusted odds ratio of spontaneous abortion for paternal lead exposure, obtained from a logistic regression model. ( $\mathrm{PbB}=$ blood lead)

Variable $\quad$\begin{tabular}{c}
$95 \%$ \\
Odds ratio \\
$\begin{array}{c}95 \text { confidence } \\
\text { interval }\end{array}$ \\
\hline
\end{tabular}

Paternal exposure

Estimated PbB lead level

$\begin{array}{ccc}<1.0 \mu \mathrm{mol} / \mathrm{l} & 1.0 & . \\ 1.0-1.4 \mu \mathrm{mol} / \mathrm{l} & 1.0 & 0.6-1.7 \\ 1.5-1.8 \mu \mathrm{mol} / \mathrm{l} & 1.3 & 0.5-3.4 \\ \geq 1.9 \mu \mathrm{mol} / \mathrm{l} & 1.6 & 0.6-4.0 \\ \text { Cadmium } & 1.4 & 0.6-3.4 \\ \text { Mercury } & 0.8 & 0.1-5.6\end{array}$

Mercury $0.1-5.6$

Maternal exposure

Organic solvents $\quad 1.9 \quad 0.8-4.6$

$\begin{array}{lll}\text { Mercury } & 2.2 & 0.5-10.6\end{array}$

Use of alcohol $\geq 1$ time a week $\quad 2.8 \quad 0.8-9.0$

Parity $\geq 3$ children $\quad 1.6 \quad 0.7-3.7$

Contraception $^{\mathrm{a}} \quad 2.2 \quad 1.2-4.2$

Previous spontaneous abortion $\quad 1.8 \quad 1.1-3.0$

Index of missing information $\quad 1.2 \quad 0.7-2.1$

a includes oral contraceptives, intrauterine devices, and spermicides.

workers monitored before or after the spermatogenesis. If their nearest $\mathrm{PbB}$ measurements had been used as such in the multivariate analysis, the odds ratio would have been $0.9(95 \% \mathrm{CI} 0.5-1.4)$ for the $\mathrm{PbB}$ level 1.0-1.4, 0.8 (95\% CI 0.3-2.3) for the PbB level $1.5-1.8 \mu \mathrm{mol} / \mathrm{l}$, and $3.0(95 \% \mathrm{CI} 1.0-8.7)$ for the $\mathrm{PbB}$ level $\geq 1.9 \mu \mathrm{mol} / \mathrm{l}$.

The $\mathrm{PbB}$ measurements used in the assessment of exposure had been performed during or within three years of the spermatogenesis period in question. The nearer the $\mathrm{PbB}$ measurement is to the time of spermatogenesis the more accurate the estimate of lead exposure is, and its validity decreases as the time span increases. To investigate whether the risk of spontaneous abortion was the same regardless of the time span between the measurement and the spermatogenesis, we divided the study subjects into two groups. The first group included those men who had been monitored during spermatogenesis, or before as well as after it, and the measurements were within one year of the spermatogenesis. The second group included the other study subjects. The low-exposure $(\mathrm{PbB}<1.0$ $\mu \mathrm{mol} / \mathrm{l})$ category was used as a reference group. The odds ratio for the high-exposure ( $\mathrm{PbB} \geq 1.5 \mu \mathrm{mol} / \mathrm{l}$ ) category was significantly increased (OR $3.8,95 \% \mathrm{CI}$ $1.2-12.0$ ) for the first group but not (OR $0.8,95 \%$ CI $0.3-1.9$ ) for the second (table 6).

A possible difference in the odds ratio for lead exposure by age was examined with the use of separate logistic models for the younger ( $<27$ years) and older ( $\geq 27$ years) wives. The odds ratio of spontaneous abortion for the husband's lead exposure ( $\mathrm{PbB} \geq 1.0$ $\mu \mathrm{mol} / \mathrm{l})$ was significantly increased in the younger age group but not in the older age group (table 7). The age of the husband had no effect on the association between the risk of abortion and lead exposure. 
Among the younger wives the length of gestation (based on the wife's own report) was shorter for the higher exposure $(\mathrm{PbB} \geq 1.0 \mu \mathrm{mol} / \mathrm{l})$ than for the lower exposure (arithmetic means 10.3 versus 12.2 weeks, Student's t-test $P=0.04)$. However, the odds ratios for abortions occurring in the early ( $<11$ weeks) and later ( $\geq 11$ weeks) stage of pregnancy were almost similar. In the older age group there were no differences in the length of gestation between the two exposure categories (11.9 and 11.7 weeks, respectively).

Table 6. Adjusted odds ratio of spontaneous abortion for paternal lead exposure by timing of blood lead $(\mathrm{PbB})$ measurement and spermatogenesis, obtained from a logistic regression model. ${ }^{\mathrm{a}}$

\begin{tabular}{|c|c|c|c|c|}
\hline \multirow[b]{2}{*}{ Estimated $\mathrm{PbB}$ level } & \multicolumn{2}{|c|}{ Exposed } & \multirow[b]{2}{*}{$\begin{array}{l}\text { Odds } \\
\text { ratio }\end{array}$} & \multirow{2}{*}{$\begin{array}{l}95 \% \\
\text { confidence } \\
\text { interval }\end{array}$} \\
\hline & $\begin{array}{l}\text { Cases } \\
\text { (N) }\end{array}$ & $\begin{array}{l}\text { Refer- } \\
\text { ents } \\
\text { (N) }\end{array}$ & & \\
\hline$<1.0 \mu \mathrm{mol} / \mathrm{l}$ & 157 & 228 & 1.0 & . \\
\hline \multicolumn{5}{|c|}{$\begin{array}{l}\text { Measurement during } \\
\text { spermatogenesis, or both } \\
\text { before and after, but } \\
\text { within a year from } \\
\text { the spermatogenesis }\end{array}$} \\
\hline $\begin{array}{l}1.0-1.4 \mu \mathrm{mol} / \mathrm{l} \\
\geq 1.5 \mu \mathrm{mol} / \mathrm{l}\end{array}$ & $\begin{array}{r}7 \\
12\end{array}$ & $\begin{array}{r}15 \\
6\end{array}$ & $\begin{array}{l}0.7 \\
3.8\end{array}$ & $\begin{array}{l}0.3-1.9 \\
1.2-12.0\end{array}$ \\
\hline \multicolumn{5}{|c|}{$\begin{array}{l}\text { Other subjects measured } \\
\text { within three years or } \\
\text { exposure classified }\end{array}$} \\
\hline $\begin{array}{c}1.0-1.4 \mu \mathrm{mol} / \mathrm{l} \\
\geq 1.5 \mu \mathrm{mol} / \mathrm{l}\end{array}$ & $\begin{array}{r}29 \\
8\end{array}$ & $\begin{array}{l}36 \\
15\end{array}$ & $\begin{array}{l}1.2 \\
0.8\end{array}$ & $\begin{array}{l}0.6-2.1 \\
0.3-1.9\end{array}$ \\
\hline
\end{tabular}

a The model included the following variables: paternal exposure to cad mium and mercury; maternal exposure to organic solvents, mercury and alcohol; parity; contraception; previous spontaneous abortion; and the index of missing information.
Paternal use of alcohol modified the effect of paternal lead exposure. The interaction between these two variables was statistically significant $(P=0.005)$. Table 8 shows the odds ratios of each combination of exposure to these variables relative to no or low exposure to either variable. The adjusted odds ratio for paternal lead exposure $(\mathrm{PbB} \geq 1.0 \mu \mathrm{mol} / \mathrm{l})$ for the wives of the husbands taking $\geq 10$ drinks a week was increased (table 8). The interaction term involving lead exposure and maternal heavy lifting at work was also statistically significant $(P=0.03)$. However, the examination by exposure showed that the interaction was observed only for the lower exposure ( $\mathrm{PbB}$ 1.0-1.4 $\mu \mathrm{mol} / \mathrm{l})$ and not for the higher exposure $(\mathrm{PbB} \geq 1.5$ $\mu \mathrm{mol} / \mathrm{l})$. In addition, it was found only among the younger wives, not among the older wives.

\section{Discussion}

The results of this study did not show a statistically significant relationship between spontaneous abortion and paternal exposure to lead at the contemporary occupational exposure levels found in Finland. Because of the small numbers, no firm conclusions concerning the highest exposure $(\mathrm{PbB} \geq 1.9 \mu \mathrm{mol} / \mathrm{l}) \mathrm{can}$ be drawn. A detailed examination of the distribution of the study subjects in this category showed that the husbands of six case mothers but only one referent mother had a blood lead value of $\geq 2.5 \mu \mathrm{mol} / 1$. These results were obtained in the analysis which included all the men who had a $\mathrm{PbB}$ measurement within three years

Table 7. Odds ratio of spontaneous abortion for paternal lead exposure by wife's age, logistic regression models. ( $\mathrm{PbB}=$ blood lead)

\begin{tabular}{|c|c|c|c|c|c|c|c|}
\hline \multirow{3}{*}{$\begin{array}{l}\text { Estimated } \\
\text { PbB level }\end{array}$} & \multicolumn{6}{|c|}{ Wife's age } & \multirow{3}{*}{$\begin{array}{l}\text { P-value for } \\
\text { homogeneity of the } \\
\text { odds ratio in the } \\
\text { two age groups }\end{array}$} \\
\hline & \multicolumn{3}{|c|}{$<27$ years } & \multicolumn{3}{|c|}{$\geq 27$ years } & \\
\hline & $\begin{array}{l}\text { Exposed } \\
\text { cases/ } \\
\text { referents }\end{array}$ & $\begin{array}{l}\text { Odds } \\
\text { ratio }\end{array}$ & $\begin{array}{c}95 \% \\
\text { confidence } \\
\text { interval }\end{array}$ & $\begin{array}{l}\text { Exposed } \\
\text { cases/ } \\
\text { referents }\end{array}$ & $\begin{array}{l}\text { Odds } \\
\text { ratio }\end{array}$ & $\begin{array}{c}95 \% \\
\text { confidence } \\
\text { interval }\end{array}$ & \\
\hline $\begin{array}{l}<1.0 \mu \mathrm{mol} / / \\
\geq 1.0 \mu \mathrm{mol} / /\end{array}$ & $\begin{array}{l}64 / 110 \\
36 / 31\end{array}$ & $\begin{array}{l}1.0 \\
2.2\end{array}$ & $1.2-4.1$ & $\begin{array}{l}93 / 118 \\
20 / 41\end{array}$ & $\begin{array}{l}1.0 \\
0.6\end{array}$ & $0.3-1.2$ & $<0.01$ \\
\hline
\end{tabular}

Table 8. Adjusted odds ratio of spontaneous abortion for paternal lead exposure by paternal use of alcohol, obtained from a logistic regression model. ${ }^{\mathrm{a}}(\mathrm{PbB}=$ blood lead)

\begin{tabular}{|c|c|c|c|c|c|c|}
\hline \multirow{3}{*}{ Paternal alcohol use } & \multicolumn{6}{|c|}{ Estimated $\mathrm{PbB}$ level } \\
\hline & \multicolumn{3}{|c|}{$<1.0 \mu \mathrm{mol} / \mathrm{l}$} & \multicolumn{3}{|c|}{$\geq 1.0 \mu \mathrm{mol} / \mathrm{l}$} \\
\hline & $\begin{array}{l}\text { Casesl } \\
\text { referents }\end{array}$ & $\begin{array}{l}\text { Odds } \\
\text { ratio }\end{array}$ & $\begin{array}{c}95 \% \\
\text { confidence } \\
\text { interval }\end{array}$ & $\begin{array}{l}\text { Cases/ } \\
\text { referents }\end{array}$ & $\begin{array}{l}\text { Odds } \\
\text { ratio }\end{array}$ & $\begin{array}{c}95 \% \\
\text { confidence } \\
\text { interval }\end{array}$ \\
\hline $\begin{array}{l}<10 \text { drinks a week } \\
\geq 10 \text { drinks a week }\end{array}$ & $\begin{array}{c}130 / 165 \\
27 / 61\end{array}$ & $\begin{array}{l}1.0 \\
0.5\end{array}$ & $0.3-0.9$ & $\begin{array}{l}35 / 59 \\
21 / 13\end{array}$ & $\begin{array}{l}0.8 \\
2.0\end{array}$ & $\begin{array}{l}0.5-1.3 \\
0.9-4.7\end{array}$ \\
\hline
\end{tabular}

a The model included the following variables: paternal exposure to cadmium and mercury; maternal exposure to organic solvents, mercury and alcohol; parity; contraception; previous spontaneous abortion; and the index of missing information. 
of spermatogenesis or whose exposure was classified on the basis of the questionnaire data. When the odds ratio for paternal lead exposure was calculated for those wives whose husbands had been monitored during or close to spermatogenesis, a statistically significant increase in the risk of abortion was observed. The association between the husband's lead exposure and spontaneous abortion was modified also by the age of the wife, paternal use of alcohol, and maternal heavy lifting.

It is possible that the differences in the results between those monitored during or close to the time of spermatogenesis in question and the other subjects are caused by misclassification of exposure in the latter group. The exposure assessment is the most accurate if the $\mathrm{PbB}$ measurement is taken at a time close to the spermatogenesis. The latter group also included workers whose exposure assessment was based on questionnaire data or whose PbB measurements were performed one to three years from the spermatogenesis.

The observation of an increased risk of abortion among the younger but not among the older wives of lead-exposed husbands was unexpected. It does not seem plausible that the pregnancy would end in spontaneous abortion more easily among younger than older women, rather the opposite. The finding may be due to some occupational factor or exposure associated with maternal age and lead exposure. However, in the comparison of the work tasks between the husbands of the young and older wives, no such differences were found which could explain the result.

Our data do not include very early unrecognized spontaneous abortions not treated in hospitals. One potential explanation for the age effect could be that the pregnancies of the older wives of exposed men end already at the subclinical stage. The observation may also be explained by the high inherent background risk of spontaneous abortion among older women. The incremental risk due to occupational exposure may be difficult to observe because of the higher background risk of older women.

Paternal use of alcohol appeared to modify the effect of lead exposure on spontaneous abortion. The odds ratio for lead exposure was increased among the wives of the husbands consuming more than 10 drinks a week, but not among the wives of the husbands consuming less alcohol. For animals, paternal alcohol exposure has been reported to lower resistance to environmental toxins, decrease litter size, and increase dominant lethal mutations $(15,16)$. Very little is known about the effects of human paternal alcohol use on offspring, but alcohol can affect sperm count, motility, and morphology (17).

In this study, $14 \%$ of the cases had $\geq 2$ registered spontaneous abortions within the present marriage during the study period. The referents had no registered spontaneous abortions within this period because only one pregnancy per woman was allowed. The analysis of the effect of lead exposure yielded similar results among all the study subjects and among those without other adverse pregnancy outcome. This finding suggests that the restriction used in the selection of the referents did not affect the results.

\section{Validity of the exposure assessment}

The assessment of lead exposure was made for $56 \%$ of the study subjects on the basis of individual measurements of the $\mathrm{PbB}$ concentration. As the measurements were independent of the worker's own reporting of lead exposure, the possibility of recall bias was minimal. Another advantage of using biological monitoring data was that they provided an internal measurement of exposure specific to individuals (18).

The problems in using $\mathrm{PbB}$ values for exposure assessment are related to the time span between the exposure measurement and the spermatogenesis. Only $6 \%$ of the workers had been measured during the spermatogenesis. The $\mathrm{PbB}$ concentration mainly indicates recent exposure (19), and the half-time of lead in blood is about $30 \mathrm{~d}$.

We assessed the exposure of the workers not monitored during the period of spermatogenesis in question by correcting the nearest $\mathrm{PbB}$ measurement according to the decreasing trend observed among the monitored workers. The correction was applied for $37 \%$ of the study subjects. In general, the correction affected only slightly the distribution of the cases and the referents into different exposure categories. The exposure was changed for $13 \%$ of the study subjects. The effect of the correction was the greatest in the highest exposure $(\mathrm{PbB} \geq 1.9 \mu \mathrm{mol} / \mathrm{l})$, where it decreased the number of cases by one and increased the number of referents by five.

Possible errors in the assessment of exposure of the men monitored, but not during the period of spermatogenesis in question or very close to it, may arise for different reasons. First, if a person has been monitored after work tasks with occasional high exposure, the use of the $\mathrm{PbB}$ values for assessing exposure results in false positive findings. Second, the trend in lead exposure in workplaces where biological monitoring was started after the time of interest may not be the same as that in workplaces where the workers have been monitored throughout the study period. Third, although a decreasing trend in the $\mathrm{PbB}$ results was observed for most of the important lead industries, there were differences in the rate of the decline between various industries (Ahti Anttila, an unpublished observation).

The validity of the exposure assessment using corrected $\mathrm{PbB}$ values was examined in a small subpopulation monitored during the period of spermatogenesis in question and before or after it or both. The actual $\mathrm{PbB}$ value measured during the period of spermatogenesis of interest was compared to that estimated from the adjacent measurement $(N=96)$. Ninety-three percent of the men truly exposed during the period of spermatogenesis of interest would have been classified 
as exposed $(\mathrm{PbB} \geq 1.0 \mu \mathrm{mol} / \mathrm{l})$ if the corrected values had been used. Similarly, $82 \%$ of the truly unexposed men had been classified as unexposed. None of the unexposed men were moved to the highest exposure category. The results of the comparison are only suggestive, as they are based on a small well-monitored subpopulation, with a high prevalence of exposure. Nevertheless, they suggest a fairly high sensitivity and slightly lower specificity of the exposure classification. It is likely, however, that in the total study population the specificity is higher because the number of unexposed persons is greater.

The subjects who had not been biologically monitored in their job of interest were blindly classified into exposure categories on the basis of the questionnaire data. The classification used information on the occupation, detailed description of the work tasks, answers to questions on typical work tasks involving lead exposure, and possible lead measurements made in corresponding jobs. As the exposure classification was made on the basis of the workers' own answers, potential recall bias may have induced differential misclassification of exposure.

The comparison of the workers' own reports of lead exposure and the lead measurements among the men monitored within one year from the time of interest indicated that $31 \%$ of the occupationally exposed workers $(\mathrm{PbB} \geq 1.0 \mu \mathrm{mol} / \mathrm{l})$ did not report lead exposure in the questionnaire. Underreporting of exposure was more common among the referents (34\%) than among the cases $(24 \%)$. On the basis of this observation, differential misclassification of exposure arising from selective recall cannot be excluded. The probability of differential misclassification is small, however, since during the time period of interest most of the classified subjects worked in occupations where there was no lead exposure or it was usually below the limit of occupational exposure.

\section{Response bias}

The response rate was moderate in this study, and there was no essential difference between the cases and the referents. The participation was examined according to the level of lead exposure among all those subjects who had been measured during the period of spermatogenesis of interest $(\mathrm{N}=75)$. The response rate was higher among the less exposed $(<1.0 \mu \mathrm{mol} / \mathrm{l})$ than among the more heavily exposed $(\geq 1.0 \mu \mathrm{mol} / \mathrm{l})$ persons.

In order to examine the possible effect of participation on the results, we calculated an odds ratio of spontaneous abortion for lead exposure among all the study subjects, including responding and nonresponding subjects who had been monitored during the period of spermatogenesis in question. The crude odds ratios were 2.5 ( 8 cases versus 10 referents), 2.1 ( 4 cases versus 6 referents), and 2.5 ( 8 cases versus 10 referents) for $\mathrm{PbB}$ concentrations of $1.0-1.4,1.5-1.8$, and $\geq 1.9 \mu \mathrm{mol} / 1$ when the low-exposure $(\mathrm{PbB}<1.0$ $\mu \mathrm{mol} / \mathrm{l})$ was used as the reference group ( 7 cases versus 22 referents). The results of the two highest categories are compatible with that observed for the workers monitored during or close to the period of spermatogenesis in question.

\section{Validity of the pregnancy data}

In this study information on the pregnancy outcome was obtained from a nationwide data base on medically diagnosed pregnancies. The study subjects confirmed almost all of the births and $84 \%$ of the spontaneous abortions. The confirmation of spontaneous abortion was related to the time elapsed since abortion, recent events being reported to a higher degree than more distant ones. The inclusion of the unconfirmed abortions in the analysis did not change the results observed for the original population.

\section{Concluding remarks}

The findings of this study suggest that there may be an association between paternal lead exposure and the risk of spontaneous abortion among the wives of leadexposed men. The results suggest also that there is an interaction effect between the age of the wife and the husband's lead exposure, as well as between paternal use of alcohol and the husband's lead exposure.

Simultaneous exposure to other metals and organic solvents was frequent among the study subjects and thus combined and/or confounding effects of exposures cannot be excluded. Paternal lead exposure may increase subfertility and the number of very early spontaneous abortions, phenomena which also may have affected the results of the study. We have studied only whether paternal exposure to inorganic lead during the period of spermatogenesis in question is associated with clinical spontaneous abortion. Earlier long-term exposure to lead might also have an effect on sperm or germ cells and thus the risk of spontaneous abortion. In addition, possible effects of secondary maternal exposure by contact with clothes or by semen cannot be excluded.

Further epidemiologic studies on the reproductive hazards of paternal lead exposure are needed to confirm or refute the present findings.

\section{Acknowledgments}

We wish to thank Mr P Kyyrönen for his valuable comments and statistical advice and Mr T Hemminki, Ms $T$ Nikula, and the staff of the Biochemistry Laboratory at the Institute of Occupational Health for their skillful technical assistance.

This study was supported by grant RO1-OH01919 from the United States National Institute for Occupational Safety and Health. 


\section{References}

1. Uzych L. Teratogenesis and mutagenesis associated with the exposure of human males to lead: a review. Yale $\mathrm{J}$ Biol Med 1985;58:9-17.

2. Beckman L, Nordström S. Occupational and environmental risks in and around a smelter in Northern Sweden: IX. fetal mortality among the wives of smelter workers. Hereditas 1982;97:1-7.

3. Thomas JA, Brogan III WC. Some actions of lead on the sperm and on the male reproductive system. Am J Ind Med 1983;4:127-34.

4. Plechaty MM, Noll B, Sunderman FW Jr. Lead concentrations in semen of healthy men without occupational exposure to lead. Ann Clin Lab Sci 1977;7: $515-8$.

5. Lancranjan I, Popescu HI, Gavanescu O, Klepsch I, Serbanescu M. Reproductive ability of workmen occupationally exposed to lead. Arch Environ Health 1975; 30:396-401.

6. Assennato G, Molinini R, Paci C, et al. Sperm count suppression without endocrine dysfunction in leadexposed men. Arch Environ Health 1987;42:124-7.

7. Viskum S. Sædkvalitet og blypåvirkning [Sperm quality and the effect of lead]. In: Arbejdsmiljøfondet. Nordisk forskningskonference om fertilitet og arbejdsmiljø Copenhagen: Arbejdsmiljøfondet, 1989:9.

8. Tuohimaa P, Wichmann L. Sperm production of men working under heavy-metal or organic-solvent exposure. In: Hemminki K, Sorsa M, Vainio H, ed. Occupational hazards and reproduction. Washington, DC: Hemisphere Publishing Corporation, 1985:73-9.

9. Wildt K, Eliasson R, Berlin M. Effects of occupational exposure to lead on sperm and semen. In: Clarkson TW, Nordberg GF, Sager PR, ed. Reproductive and developmental toxicity of metals. New York, NY: Plenum Press, 1983:279-300.
10. Furuhjelm M, Jonson B, Lagergren C-G. The quality of human semen in spontaneous abortion. Int J Fertil 1962;7:17-21.

11. Hernberg S. Lead. In: Aitio A, Riihimäki V, Vainio H, ed. Biological monitoring and surveillance of workers exposed to chemicals. Washington, DC: Hemisphere Publishing Corporation, 1984:19-27.

12. Lindbohm ML, Hemminki $K$. A nationwide data base on medically diagnosed spontaneous abortions in Finland. Int J Epidemiol 1988;17:568-73.

13. Overstreet JW, Blazak WF. The biology of human male reproduction: an overview. Am J Ind Med 1983;4:5-15.

14. Breslow NE, Day NE. Statistical methods in cancer research; vol 1 (The analysis of case-control studies). Lyon: International Agency for Research on Cancer, 1980. (IARC scientific publications; no 32.)

15. Cohen FL. Paternal contributions to birth defects. Nurs Clin North Am 1986;21:49-64.

16. Wyrobek AJ, Gordon LA, Burkhart JG, et al. An evaluation of human sperm as indicators of chemically induced alterations of spermatogenic function. Mutat Res 1983;115:73-148.

17. International Agency for Research on Cancer. Alcohol drinking. Lyon: International Agency for Research on Cancer, 1988. (IARC monographs on the evaluation of carcinogenic risks to humans; vol 44.)

18. Lemasters GK, Selevan SG. Use of exposure data in occupational reproductive studies. Scand J Work Environ Health 1984;10:1-6.

19. Kazantzis G. The use of blood in the biological monitoring of toxic metals. In: Clarkson T, Friberg L, Nordberg G, Sager P, ed. Biological monitoring of toxic metals. New York, NY: Plenum Press, 1988:547-65.

Received for publication: 13 March 1990 